industrial expansion is the aggravated pollution problem occasioned by increased volumes of trade effuent, frequently of a highly complex character. He accepts the view that trade effluents are best disposed of by discharge to the public sewers, provided that treatment is applied to the effluents so that they will not damage the sewers, or cause danger to workmen, or interfere with the processes of purification of sewage. Methods of removing constituents most likely to cause difficulty are outlined, and an organized system of trade effluent inspection and control operated by the local authority is advocated to ensure co-operation between the authority and manufacturers.

Dealing with the obligations imposed by the pollution prevention Acts, Mr. M. Lovett directs attention to the fact that, although during the interim period of seven years after the passing of the 1951 Act a river board may not, without the consent of the Minister of Housing and Local Government, institute legal proceedings against a person who "causes or knowingly permits to enter a stream any poisonous, noxious or polluting matter", the consent of the Minister is not required for proceedings against an offender who fails to comply with valid conditions of consent relating to a new discharge. A new feature which is referred to is that river boards may now 'apprehend' that a contravention of the Act is likely to occur as a result of a proposed use of a stream, and, subject to the consent of the Minister during the interim period, may obtain an order prohibiting the use complained of. The author, however, emphasizes that river boards are much more anxious to abate pollution than to institute legal proceedings.

In four of the five examples of methods of treatment of industrial organic wastes brought together by Dr. D. H. Sharp, biological oxidation forms the final stage, after preliminary chemical and physical treatment to remove substances which would otherwise interfere with biological action. Perhaps the most interesting of these preliminary treatments is that applied to the waste water from the manufacture of pesticides. These contain bactericidal and toxic compounds which are removed partly by adsorption on activated charcoal and partly by chemical precipitation before the neutralized and diluted waste is applied to percolating filters.

The paper on acid wastes by Dr. S. H. Jenkins and Mr. C. H. Hewitt is of particular interest in the Birmingham district, where a great deal of metal working is done, with consequent discharge of acid liquors and washings from preliminary pickling of the metal. Examples of acid discharges are quoted which reduced the $p H$ value of sewage reaching a treatment works to less than 3 for several hours. At this degree of acidity damage to the sewer occurs, the conversion of urea to ammonia is inhibited, and there is serious depression of the biological activity on which purification of sewage depends. Neutralization of acid discharges is therefore essential, and the authors describe (with illustrations) a range of neutralization plants of different sizes and designs.

Discharge of electro-plating wastes is also very common in the Midlands, and in a paper on treatment of these liquids Mr. A. E. J. Pettet stresses the need to consider conservation of water and chemicals in the plating shop before treatment of wastes unavoidably discharged is undertaken. Chemical methods of oxidation, reduction or precipitation are usually used for treatment, but cyanides can be destroyed biologically. Waste chromic acid anodizing solutions can be regenerated for re-use by means of recently developed ion-exchange resins resistant to the action of this acid.

The disposal of gas works effluents, dealt with by Mr. W. T. Lockett, is a problem of national concern, and investigators in the Midlands are particularly active in seeking a solution. The author traces the changing nature of the problem from the time when horizontal gas retorts were in use, ammonia was worth recovering from the liquor, and each gas works served a restricted area, to the present day when vertical retorts are most commonly used, ammonia can be recovered only at a loss, and small gas works are being superseded by centralized works serving large areas. Investigations fifty years ago showed that gas liquor could be treated biologically, the researches of the Institution of Gas Engineers during 1928-37 defined the conditions under which gas liquor could be satisfactorily treated when mixed with sewage, and revealed that certain changes in the operation of gas works could make treatment easier, and present-day researches are concerned with both chemical and high-rate biological methods of treatment.

Much discussion, reported in a separate booklet, centred around the mode of application of the 1937, 1948 and 1951 Acts and the cost to manufacturers and local authorities of treating industrial effluents. It was urged that by alteration of processes and by using conservation methods within factories, water and valuable materials could be saved and the cost and difficulty of treatment could be much reduced. Among examples quoted were that in one factory waste sulphonation acid was reconcentrated to give a crude but saleable product, and that in another small factory 10,000 gallons of water were saved a day by alteration of process and by introduction of a re-circulatory water system. A. E. J. Perter

\title{
BASIC RESEARCH IN THE UNITED STATES
}

\begin{abstract}
$\mathrm{D}$ ETAILS of expenditure on basic research in the United States are given in various surveys published by the National Science Foundation, but the report "Basic Research-A National Resource", recently issued by the Foundation, is more in the lineage of Vannevar Bush's "Science-The Endless Frontier" and the Steelman report, "Science and Public Policy". It attempts to convey to the general citizen the meaning of basic scientific research and its bearing on the national economy, welfare and
\end{abstract}

security. The growth of basic research in the United States is briefly described in a chapter which illustrates some of the possibilities implicit to-day in virus research, in translation by electronic methods and in the study of other problems of social communication in leadership. After a brief reference to some unsolved problems, the following chapter outlines the present position of basic research in the United States, both in scale and in organization, while in the final chapter the strength- 
ening of basic research is discussed and various suggestions listed in the general summary are amplified.

Stress is laid upon the establishment of more favourable conditions for its continued growth, including an increasing awareness on the part of the public of the methods, aims and significance-cultural as well as material--of basic research, as well as upon increased financial support. A more active participation by private industry is particularly urged as well as reduction in the amount of development work in universities and colleges under contract with Government agencies. Although in general terms the report contains little that is not to be found in the Barlow and other reports in Great Britain, it presents the case for basic research in cogent terms that are equally applicable in Britain and elsewhere.

\title{
ORIGIN OF CHONDRULES IN METEORITIC STONES
}

\author{
By DR. L. J. SPENCER, C.B.E., F.R.S.
}

$\mathrm{T}$ HE chondrules ( $\chi o ́ v \delta \rho \circ$, a grain) in meteoritic stones are quite distinct from the spherulites in terrestrial volcanic rocks and from the ooliths and sand grains in sedimentary rocks. They occur in chondrites (chondritic meteoritic stones); other rarer meteoritic stones in which they are not present are classed as achondrites. They are usually quite small (I-3 mm.), about the size of millet seed, usually spherical, and are embedded in a finely brecciated matrix of the same materials (olivine, pyroxene, felspar, glass, nickel-iron, etc.) of which they themselves are composed.

Their mode of origin has long been a puzzle, giving rise to much speculation. In recent reviews' ${ }^{1}$ of the various hypotheses, mention has been made, but with little support, of an early suggestion by H. C. Sorby ${ }^{2}$ of glassy globules of 'fiery rain'. This mention of 'fiery rain' calls to mind the findings at the meteorite craters of Wabar in Arabia ${ }^{3}$.

Mr. H. St.J. B. Philby's expedition in 1932, with eighteen Arabs and thirty-two camels wandering in the desert for three months, had the object of finding the legendary city of Wabar, supposed to have been "destroyed by fire from heaven". Two meteorite craters were found, and there were indications of others buried beneath the desert sand; their walls are formed of cindery blocks and bombs of silica glass. Nearby, pieces of meteoritic iron were collected, the largest weighing $25 \mathrm{lb}$.; but a mass of iron as "big as a camel" could not be found. The locality is known to the Arabs as Al Hadida (place of the iron). Scattered around were numerous shining black pellets. These were thought by the Arabs to be pearls, blackened by the fire, that had been worn by the ladies of the court of the wicked king 'Ad ibn Kin'ad. With a lust for wealth, the Arabs filled the camel saddle-bags with these 'pearls', but on the return to Mecca they were rejected by the dealers and thrown away. Fortunately, a few were preserved in Mr. Philby's collection. These consist of a vesicular white silica-glass $\mathrm{SiO}_{2}$, 92.88 per cent), coated outside with a lustrous black glass $\left(\mathrm{SiO}_{2}, 87.45\right.$ per cent), with some iron and nickel.

Larger blocks or bombs show in some cases a corrugated surface resembling ropy lava, and covered with minute pimples, which perhaps represent dew-drops of silica. Broken surfaces show a breccia of white, grey, and black glass with a few shattered grains of quartz, and many round bubbles varying widely in size. Thin sections under the microscope show in addition large numbers of minute black specks. These specks I had at first assumed to be small holes filled with the grinding and polishing materials used in the preparation of the sections. But Dr. Leonard Hawkes, when he crushed a frag. ment of the glass on a microscope slide, saw minute metallic spheres rolling about. A piece of the glass crushed (not ground) in an agate mortar yielded a powder from which a magnetic needle picked up bunches of bright spheres by the thousands. These range from 0.1 to $0.0005 \mathrm{~mm}$. in diameter. Two counts of the black dots over areas of a square millimetre on the thin sections gave estimates of one and two million in a cubic centimetre of the glass.

In a solution of copper sulphate the spheres become coated with copper. Analyses gave: Fe 91.2, Ni 8.8 per cent; $\mathrm{F} \theta: \mathrm{Ni}=10 \cdot 4$, as compared with 12.6 in the meteorite. X-ray examination by Dr. F. A. Bannister showed the material to be bodycentred cubic $\alpha$-iron. Metallographic examination by Dr. J. M. Robertson showed that the smaller spheres consist of a single crystal, while larger ones consist of several crystals with inclusions (probably silica-glass) between the irregular boundaries of the grains.

At Wabar there evidently was a shower of large masses of meteoritic iron. The sudden transformation of the kinetic energy into heat gave rise to violent explosions, and broken fragments of iron were ejected from the craters. The Earth's atmosphere was blasted aside by vapours of iron and nickel, and of silica (from the desert sand). Temperatures were far in excess of :

$\begin{array}{lccc} & \text { Nickel } & \text { Iron } & \text { Silica } \\ & \left({ }^{\circ} \mathrm{C} .\right) & \left({ }^{\circ} \mathrm{C} .\right) & \left({ }^{\circ} \mathrm{C} .\right) \\ \text { Melting point } & 1,452 & 1,535 & 2,900 \\ \text { Boiling point } & 2,900 & 3,200 & 3,500 \text { ? }\end{array}$

A rain, or rather drizzle, of globules of molten nickel-iron and silica fell into pools of boiling silica. Conditions such as these, with some variations, would seem to be quite suitable for the formation of chondrites.

A shower of hail-stones into a mush of broken snowflakes (both grown from water-vapour) would produce a somewhat similar structure. Curious hail-stones fell at Menabilly in Cornwall on October 20, 1791. One of them, weighing nearly one ounce, was sketched by Philip Rashleigh and a glass model was made. Enclosed in clear ice were four white spherical hail-stones of the usual kind". This is perhaps another example of chondritic structure.

At other meteorite craters different conditions have prevailed. The Tunguska meteorite of 1908 in central Siberia appears to have been entirely vaporized, and only quite recently have traces of meteoritic material been detected in soil samples ${ }^{5}$. The Meteor Crater in 